\title{
Economic Valuation and Sensitivity Analysis of Triple Has Prospect Under Gross Split PSC at PT. Pertamina Hulu Energi Offshore Southeast Sumatra (PT. PHE OSES)
}

\author{
Ardian Aby Santosa*, Widhyawan P \\ School of Business and Management ITB \\ Bandung, Indonesia \\ *ardian.santosa@sbm-itb.ac.id
}

\author{
Anik Irawati, Rifqi L.D, Sri Hartanto \\ PT. Pertamina Hulu Energi Offshore Southeast Sumatra \\ (PT. PHE OSES) \\ Jakarta, Indonesia
}

\begin{abstract}
Offshore South East Sumatra Block is an active oil and gas block in Indonesia operated by PT. Pertamina Upstream Energy Offshore South East Sumatra (PT. PHE OSES). The research framework of the economic valuation is started with evaluating the business environment for PT. PHE OSES based on external situation and internal organization analysis (PESTEL, Porter Five forces and SWOT) to identify the dynamic situation and the potential consequences to the organization. The business environment analysis will be followed by economic valuation and sensitivity analysis to available investment opportunity using capital budgeting framework which are simulated during the economic life of prospect field under the gross split scheme. Business strategy that was initially designed by considering the external business environment and internal situation of the organization is expected to ensure the organization to sustain the competitive advantage and heading the right direction otherwise business decision that was made without understanding the business environment change could risk the organization to invest in non-sustainable business opportunity. Future discussion with the stakeholders in energy business might be required to provide insights on methods to stimulate the oil and gas business without jeopardizing the State interest. Oil production control and efficiency of Capital Expenditure and being two most influential factor in the viability study of investment in the Triple-Has prospect, thus it is highly recommended to be the focus of PT. PHE OSES to expand the economic value of TripleHas prospect.
\end{abstract}

Keywords-economic valuation, sensitivity analysis, PESTEL, Porter Five forces and SWOT

\section{INTRODUCTION}

PT. Pertamina, as a state-owned company, has been appointed by the Government of Indonesia (GOI) to continue the management of the Offshore South East Sumatra (OSES) block for 20 years, from September 2018 to September 2038 through its subsidiary PT. Pertamina Hulu Energy Offshore Southeast Sumatra (PT. PHE OSES).
The block has been producing hydrocarbon since 1968, thus can be considered as mature field. The limited amount of proven reserves has encouraged further exploration activities to maintain the production of the OSES Block until the end of PSC term. Triple-Has prospect is one of the promising undeveloped prospects in OSES block. The prospect is located approximately $92 \mathrm{Km}$ from the Jakarta coastline. This prospect is located to the southeast of the Zelda production field with the discovery of oil and gas from early wells. The development plan for Triple- Has consist of 9 development wells with single platform that are planning for production in 2024. Furthermore, Triple-Has prospect will be functioned as hub for other prospects in Angel Cluster.

The framework of the economic valuation is started with evaluating the business environment for PT. PHE OSES based on external situation and internal organization analysis (PESTEL, Porter Five forces and SWOT) to identify the dynamic situation and the potential consequences to the organization. The business environment analysis will be followed by economic valuation and sensitivity analysis to available investment opportunity using capital budgeting framework which are simulated during the economic life of prospect field under the gross split scheme.

The relevant economic indicators used in this study namely Net Cash Flow (NCF), Net Present Value (NPV) and Internal Rate of Return (IRR). The calculation of net cash flow projections generated through the end of PSC period can shows whether the project has a value that is balanced with the risk of investments made. Sensitivity analysis is calculated by evaluating the impact of predetermined parameters changes in oil and gas production, oil and gas price as well Capital and Operating Expenditures on the financial forecast of investment in Triple-Has Prospect.

Business strategy that was designed by considering the external business environment and internal situation of the organization is expected to ensure the organization to sustain 
the competitive advantage [1] and heading the right direction otherwise business decision that was made without understanding the business environment change could risk the organization to invest in non-sustainable business opportunity.

\section{LITERATURE REVIEW}

The government has the right and authority to determine the use of models and patterns of upstream oil and gas management and make related regulations as shown in Figure 1. As a result, the government can determine how much risk will be borne by investors. In addition, the government has the authority to issue tax rules that are burdensome to investors or vice versa [2]. The government can also make long and multilayered rules for tiered control or supervision needs in the interests of the State, but it has the power to reduce rules or eliminate them to avoid overlapping or simplification of procedures. Indonesia PSC history and revision can be seen on table 1 bellow.

TABLE I. INDONESIA PSC HISTORY AND REVISION [3]

\begin{tabular}{|c|c|c|c|c|c|c|c|}
\hline Element & $\begin{array}{c}\text { 1st Generation } \\
\text { PSC (1965 - } \\
\text { 1975) }\end{array}$ & $\begin{array}{c}\text { 2nd } \\
\text { Generation } \\
\text { PSC (1976 - } \\
\text { 1987) } \\
\end{array}$ & $\begin{array}{c}\text { 3rd } \\
\text { Generation } \\
\text { PSC (1988 - } \\
\text { 2001) } \\
\end{array}$ & $\begin{array}{c}\text { 4th Generation } 1995 \\
\text { East Indonesia } \\
\text { Incentive } \\
(1995-\mathbf{2 0 0 1}) \\
\end{array}$ & $\begin{array}{c}\text { 5th Generation } \\
\text { Post Law no } \\
\text { 22/2001 } \\
(2002-2007) \\
\end{array}$ & $\begin{array}{c}\text { 6th } \\
\text { Generation } \\
\text { New Contracts } \\
(2008-\mathbf{2 0 1 6}) \\
\end{array}$ & $\begin{array}{c}\text { 7th Generation } \\
\text { Gross Split } \\
\text { (2017 - Present) }\end{array}$ \\
\hline FTP & None & None & $20 \%$ & $15 \%$ & $\begin{array}{l}10 \% \text { to BPMIGAS } \\
\text { not to be shared } \\
\text { with Contractor }\end{array}$ & $\begin{array}{l}20 \% \text { to } \\
\text { BPMIGAS not } \\
\text { to be shared } \\
\text { with Contractor }\end{array}$ & None \\
\hline $\begin{array}{l}\text { Cost Recovery } \\
\text { Limit }\end{array}$ & $40 \%$ & $100 \%$ & $80 \%$ & $85 \%$ & $90 \%$ & $\begin{array}{l}\text { POD Basis } \\
\text { (Ring Fencing) }\end{array}$ & None \\
\hline Income Tax & - & $56 \%$ & $48 \%$ & $44 \%$ & $44 \%$ & $40 \%$ & $40 \%$ \\
\hline $\begin{array}{l}\text { Equity Split } \\
\text { Government / } \\
\text { Contractor } \\
\text { After Tax }\end{array}$ & $\begin{array}{l}65 \% \text { / 35\% } \\
\text { (Oil) }\end{array}$ & $\begin{array}{l}85 \% \text { / } \\
\text { (Oil) } \\
70 \%, \quad 30 \% \\
\text { (Gas) }\end{array}$ & $\begin{array}{l}85 \% \text { / } 15 \% \\
\text { (Oil) } \\
70 \%, \quad 30 \% \\
\text { (Gas) }\end{array}$ & $\begin{array}{l}85 \% / 15 \% \text { (Oil) } \\
60 \% / 40 \% \text { (Gas) }\end{array}$ & $\begin{array}{l}75 \% \quad / 25 \% \text { (Oil) } \\
60 \% / 40 \% \text { (Gas) }\end{array}$ & 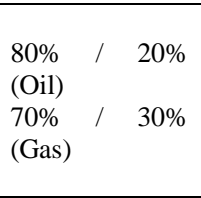 & $\begin{array}{lr}\text { Before } & \text { Tax } \\
\text { Base } & \text { Split } \\
57 \% \text { / } 43 \% & \text { (Oil) } \\
52 \% / 48 \% & \text { (Gas) } \\
\text { Variable Split } & \text { Spross Split } \\
\end{array}$ \\
\hline $\begin{array}{l}\text { Investment } \\
\text { Credit }\end{array}$ & $0 \%$ & $20 \%$ & $17 \%$ & $17 \%$ & $\begin{array}{ll}17 \% & \text { (Oil) } \\
55 \% \text { (Gas) }\end{array}$ & N/A & N/A \\
\hline DMO Oil & 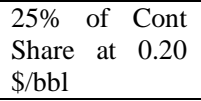 & $\begin{array}{lll}25 \% & \text { of } & \text { Cont } \\
\text { Share at } & 0.20 \\
\$ / \mathrm{bbl} & & \\
\end{array}$ & $\begin{array}{l}25 \% \text { of Cont } \\
\text { Share at } 10 \% \\
\text { of Export Price }\end{array}$ & $\begin{array}{l}25 \% \text { of Cont Share at } \\
25 \% \text { of Export Price }\end{array}$ & $\begin{array}{l}25 \% \text { of Cont } \\
\text { Share at } 10 \% \text { of } \\
\text { Export Price }\end{array}$ & $\begin{array}{l}25 \% \text { of Cont } \\
\text { Share at } 25 \% \\
\text { of Export Price }\end{array}$ & $\begin{array}{l}25 \% \text { of Cont } \\
\text { Share at } 100 \% \text { of } \\
\text { Export Price }\end{array}$ \\
\hline Depreciation & \begin{tabular}{lr}
\multicolumn{2}{l}{ No distinction } \\
between & oil \\
and gas. DDB \\
or SLD & as \\
follows: & 14 \\
years for & prod \\
facility & $3-8$ \\
years & for \\
moveavle & \\
equipmnet & $14-$ \\
20 years & for \\
others & \\
\end{tabular} & $\begin{array}{l}\text { Seve years for } \\
\text { capital cost } \\
\text { (DDB) and 10- } \\
\text { year } \\
\text { amortization of } \\
\text { non-capital cost } \\
\text { (switching to } \\
\text { SLD). Post } \\
19857 \text { year DB }\end{array}$ & $\begin{array}{l}\text { Seven years } \\
\text { DB }\end{array}$ & Seven years DB & Seven years DB & Five years DB & $\begin{array}{l}\text { Following } \\
\text { current } \\
\text { regulation }\end{array}$ \\
\hline $\begin{array}{l}\text { Interest } \\
\text { Recovery }\end{array}$ & None & Available & Available & Available & Available & None & None \\
\hline $\begin{array}{l}\text { Abandonment } \\
\text { Liability }\end{array}$ & None & None & None & $\begin{array}{l}\text { PSC require the } \\
\text { Contractor to provide } \\
\text { for abandonment }\end{array}$ & $\begin{array}{lr}\text { PSC require } & \text { the } \\
\text { Contractor } & \text { to } \\
\text { provide } & \text { for } \\
\text { abandonment } & \end{array}$ & $\begin{array}{l}\text { PSC require the } \\
\text { Contractor to } \\
\text { provide for } \\
\text { abandonment }\end{array}$ & $\begin{array}{l}\text { Following the } \\
\text { current } \\
\text { regulation }\end{array}$ \\
\hline Others & $\begin{array}{ll}\text { Cost } & \text { Oil } \\
\text { Limitation } & \end{array}$ & $\begin{array}{l}\text { No Cost Rec } \\
\text { Limit }\end{array}$ & $\begin{array}{l}\text { FTP, Cost Rec } \\
\text { Introduction }\end{array}$ & ASR is not clear state & $\begin{array}{l}\text { ASR is state in } \\
\text { Law 22/2001, but } \\
\text { no clear procedure }\end{array}$ & $\begin{array}{l}\text { ASR is state in } \\
\text { GR } 79 / 2010 \\
\text { abd PTK no.40 } \\
\text { / } 2010 \\
\text { Additional } \\
\text { Indirect Tax }\end{array}$ & $\begin{array}{l}\text {-New } \\
\text { Mechanism } \\
\text { without Cost rec } \\
\text {-Additional } \\
\text { Indirect Tax }\end{array}$ \\
\hline
\end{tabular}

The gross split psc is the new mechanism that was introduced by the Government of Indonesia back in 2017 with the issuance of regulation No. 8/2017 (which then revised with MoEMR regulation no. 20/2019) by Minister of Energy and
Mineral Resources (MoEMR) with a purpose to simplify the whole financial management aspect and to ensure the efficient and effective activities performed by Contractor [4]. 


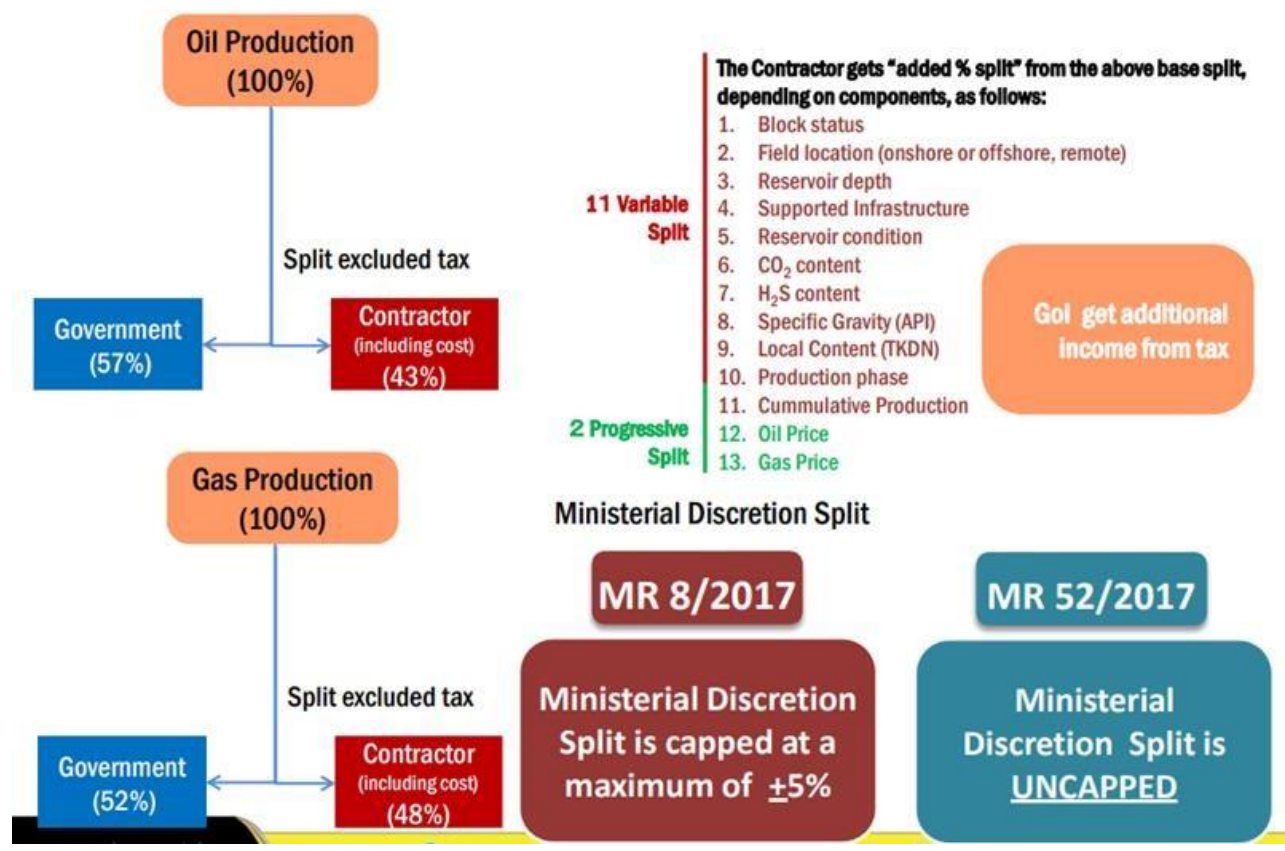

Fig. 1. PSC Cost Recovery vs PSC Gross Split [4].

One of the consequences of the Gross Split PSC is the removal cost recovery mechanism and securing the State revenue in earlier stage. In this mechanism, the Contractor must be responsible for all for operational expense that will be treated as tax reduction. As a result, the gross split mechanism will push oil and gas companies to continuously improving their efficiency. The higher the efficiency will generate more profit for the company, thus the challenge for the company is really to operate the block with the most effective and efficient method [4]. In the opposite side, if the simulated Contractor take is considerably low, the interest of Companies to invest in Indonesia oil and gas business might decreased which may cause the further slowdown to oil and gas industry in Indonesia.

The process of assessing and choose long-term investments that are purposed with the firm's objective to maximize owners' profit are defined as Capital budgeting [5]. The common indicators of a petroleum project economic analysis are net cash flow; net present value and internal rate of return.

The net cash flow of one project is the remaining cash after all the expenses are deducted in one period. To express the $\mathrm{NCF}$ annually which is associated with oil and gas project, the cash disbursements should be subtracted from cash receipts for the given period. Cash flow negative for one year is commonly not necessarily bad for the total investment; this might mean that the organization made a substantial investment at this timeline which will create large revenue later.

$\mathrm{NCF}=$ revenue $($ cash inflows $)-$ cost $($ cash outflows $)$
The net present value (NPV) is the total of all present values from each of cash flows - whether positive or negative - that happen over a project life [6]. Positive NPV means that the petroleum project is making a greater return than the hurdle rate. In cases where a debt or equity have been used to finance a new projects or assets the cost of capital should be included in the calculation [5]

$$
\mathrm{NPV}=\sum_{\mathrm{t}=1}^{\mathrm{t}=\mathrm{N}} \frac{\mathrm{CF}_{\mathrm{t}}}{(1+r)^{t}}-\text { Initial Investment }
$$

Internal Rate of Return (IRR) is a rate of return obtained from a project related to cash flow, allowing for the time value of money. IRR measures the profit ratio of an investment. The investment IRR is the discount rate that result the NPV of investment equal to zero [5]. One of the advantages using IRR is that this number can be utilized even in cases where there is no discount rate information.

\section{METHODS}

The conceptual framework of this research is start with analyzing the business environment analysis consists of: PESTEL (Political, Economy, Socio - cultural, Technology, Environment, and Legal) aspect in Indonesia oil and gas upstream business, PORTER's Five Forces and Company's SWOT (Strength, Weakness, Opportunity and Threat) analysis to recognize internal capabilities and anticipate external factors that might risk the business. The purpose of these environmental analyses is to explore and anticipate the situations that may affect project success especially field 
development of Triple-Has development plan. An economic analysis is performed as quantitative approach to determine project financial viability.

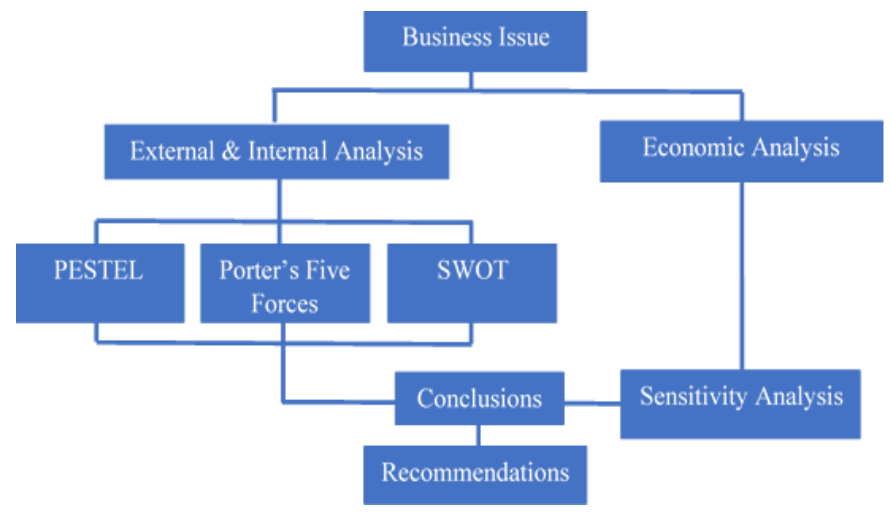

Fig. 2. Conceptual framework.

The production of oil and gas profile is obtained in relation to the development strategy that has been selected by the Contractor. The development of the prospect is including the installation of new facilities, pipeline and associated equipment followed by drilling 9 new development wells and put the well on production starting by mid-2024. The current plan is to produce the oil and gas to the end of PSC terms (2038) without drilling new infill wells. The capital expenditures and operational expenditures are estimated based on recent year data base and escalated by $2 \%$ per year. The costs then simulated throughout the life of the project.

The gross split fiscal term is used in this economic calculation based on the Ministry of Energy and Mineral Resources regulation (MoEMR) regulation No. 8/2017 which then revised with MoEMR regulation no. 20/2019. The oil price that is used in this study is based on ICP October 2019 and escalated by $2 \%$ by year. While the Gas price is using the last Contractor's Gas Sales Agreement price at USD 6.7/ mmbtu.

The variables that are exercised in the sensitivity analysis are oil and gas production, oil and gas price, capital and operating expenditure. The changes on those parameters from reference are simulated by $+/-20 \%$ to determine the effect to Net Cash Flow and Net Present Value of Contractor.

\section{RESULTS AND DISCUSSION}

Triple-Has prospect will generate gross revenue in amount of USD 2.090 billion.

TABLE II. GROSS SPLIT TABLE REFER TO MOEMR NO.52 YEAR 2017 [2].

\begin{tabular}{|c|c|}
\hline \multicolumn{2}{|c|}{ BASE SPLIT } \\
\hline \multicolumn{2}{|c|}{ OIL } \\
\hline Government & $57 \%$ \\
\hline Contractor & $43 \%$ \\
\hline GAS \\
\hline Government & $52 \%$ \\
\hline Contractor & $48 \% 0$ \\
\hline
\end{tabular}

\begin{tabular}{|c|c|}
\hline \multicolumn{2}{|c|}{ PROGRESSIVE SPLIT } \\
\hline Oil Price & Split \\
\hline \multicolumn{2}{|c|}{$(85 \$ / b b l-I C P) \times 0.25 \%$} \\
\hline Gas Price & Split \\
\hline \multicolumn{2}{|c|}{$<7$ US\$/MMBTU } \\
\hline \multicolumn{2}{|c|}{ (7 - Gas Price) $\times 2.5 \%$} \\
\hline 7-10 US\$/MMBTU & $0.0 \%$ \\
\hline \multicolumn{2}{|c|}{$>10$ US\$/MMBTU } \\
\hline \multicolumn{2}{|c|}{$(10-$ Gas Price $) \times 2.5 \%$} \\
\hline Oil and Gas Cumm & Split \\
\hline$<30 \mathrm{~mm}$ & $10 \%$ \\
\hline $30 \leq \mathrm{X}<60 \mathrm{mmboe}$ & $9 \%$ \\
\hline $60 \leq \mathrm{X}<90 \mathrm{mmboe}$ & $8 \%$ \\
\hline $90 \leq \mathrm{X}<125 \mathrm{mmboe}$ & $6 \%$ \\
\hline $125 \leq \mathrm{X}<175 \mathrm{mmboe}$ & $4 \%$ \\
\hline$\geq 175 \mathrm{mmboe}$ & $0 \%$ \\
\hline
\end{tabular}

\begin{tabular}{|c|c|}
\hline \multicolumn{2}{|c|}{ VARIABLE } \\
\hline \multicolumn{2}{|l|}{ BLOCK STATUS } \\
\hline POD I & $5.0 \%$ \\
\hline POD II & $3.0 \%$ \\
\hline POFD & $3.0 \%$ \\
\hline NO POD & $0.0 \%$ \\
\hline \multicolumn{2}{|l|}{ Field Location } \\
\hline Onshore & $0.0 \%$ \\
\hline Offshore $(0<\mathrm{h} \leq 20 \mathrm{~m})$ & $8.0 \%$ \\
\hline Offshore $(20<\mathrm{h} \leq 50 \mathrm{~m})$ & $10.0 \%$ \\
\hline Offshore $(50<\mathrm{h} \leq 150 \mathrm{~m})$ & $12.0 \%$ \\
\hline Offshore $(150<\mathrm{h} \leq 1000 \mathrm{~m})$ & $14.0 \%$ \\
\hline Offshore $(\geq 1000 \mathrm{~m})$ & $16.0 \%$ \\
\hline \multicolumn{2}{|l|}{ Reservoir Depth } \\
\hline$\leq 2500 \mathrm{~m}$ & $0.0 \%$ \\
\hline$>2500 \mathrm{~m}$ & $1.0 \%$ \\
\hline \multicolumn{2}{|l|}{ Infrastructure } \\
\hline Well Developed & $0.0 \%$ \\
\hline New Frontier Offshore & $2.0 \%$ \\
\hline New Frontier Onshore & $4.0 \%$ \\
\hline Reservoir Condition & \\
\hline Conventional & $0.0 \%$ \\
\hline Non Conventional & $16.0 \%$ \\
\hline
\end{tabular}

\begin{tabular}{|c|c|}
\hline \multicolumn{2}{|l|}{$\mathrm{CO}_{2}(\%)$} \\
\hline$<5 \%$ & $0.0 \%$ \\
\hline $5 \% \leq \mathrm{CO}_{2}<10 \%$ & $5.0 \%$ \\
\hline $10 \% \leq \mathrm{CO}_{2}<20 \%$ & $1.0 \%$ \\
\hline $20 \% \leq \mathrm{CO}_{2}<40 \%$ & $1.5 \%$ \\
\hline $40 \% \leq \mathrm{CO}_{2}<60 \%$ & $2.0 \%$ \\
\hline $\mathrm{CO}_{2} \geq 60 \%$ & $4.0 \%$ \\
\hline \multicolumn{2}{|l|}{$\mathrm{H}_{2} \mathrm{~S}(\mathrm{ppm})$} \\
\hline $\mathrm{H}_{2} \mathrm{~S}<100$ & $0.0 \%$ \\
\hline $100 \leq \mathrm{H}_{2} \mathrm{~S}<1000$ & $1.0 \%$ \\
\hline $1000 \leq \mathrm{H}_{2} \mathrm{~S}<2000$ & $2.0 \%$ \\
\hline $2000 \leq \mathrm{H}_{2} \mathrm{~S}<3000$ & $3.0 \%$ \\
\hline $3000 \leq \mathrm{H}_{2} \mathrm{~S}<4000$ & $4.0 \%$ \\
\hline $\mathrm{H}_{2} \mathrm{~S} \geq 4000$ & $5.0 \%$ \\
\hline \multicolumn{2}{|c|}{ Specific Gravity } \\
\hline API $<25$ & $1.0 \%$ \\
\hline $\mathrm{API} \geq 25$ & $0.0 \%$ \\
\hline \multicolumn{2}{|l|}{ Local Content } \\
\hline $30 \% \leq X<50 \%$ & $2.0 \%$ \\
\hline $50 \% \leq X<70 \%$ & $3.0 \%$ \\
\hline $70 \% \leq X<100 \%$ & $4.0 \%$ \\
\hline \multicolumn{2}{|l|}{ Production Stage } \\
\hline Primary & $0.0 \%$ \\
\hline Secondary & $6.0 \%$ \\
\hline Tertiary & $10.0 \%$ \\
\hline
\end{tabular}

Revenue split between the Government of Indonesia (GOI) and the Operator considers Base Split, Variable Spit and Progressive Split based on oil price and volume of oil and gas production. The components of the splits are presented in Table
2. Before split adjustment, the GOI:Contractor split is 57:43 and 52:49 for oil and gas respectively. After split adjustment the GOI:Contractor split is 30:70 and 35:65 for oil and gas respectively. 
Total contractor take is expected at USD 789,797 million (38\% of gross revenue) after deducted by Deductible cost of USD 398.166 million and Tax expense of USD 263.265 million. The Government take is estimated at USD 902.835 billion ( $43 \%$ of gross revenue) contributed by Government revenue USD 639.569 million and tax income of USD 263.265 million. The calculation can be seen on table 3 bellow.
TABLE III. REVENUE SPlit CALCUlation For TRIPle Has ProsPeCt

\begin{tabular}{|l|l|c|}
\hline \multicolumn{1}{|c|}{ Description } & \multicolumn{1}{|c|}{ Value } & $\%$ \\
\hline Total Gross Revenue Oil \& Gas (US \$) & $2,090,799,506$ & \\
\hline \multicolumn{3}{|l|}{} \\
\hline Contractor Revenue (US \$) & $1,451,229,988$ & $69 \%$ \\
\hline Deductible Expense (US \$) & $(398,166,714)$ & \\
\hline Taxable Income (US \$) & $1,053,063,274$ & \\
\hline Tax (US \$) & $263,265,818)$ & \\
\hline Total Contractor Take (US \$) & $789,797,455$ & $38 \%$ \\
\hline Average Contractor Take (US \$/year) & $56,414,104$ & \\
\hline \multicolumn{3}{|l|}{ (Author Analysis, 2019) } \\
\hline Government Revenue Gross Split (US \$) & $639,569,518$ & $31 \%$ \\
\hline Government Income Tax (US \$) & $263,265,818$ & \\
\hline Total Government Take (US \$) & $902,835,337$ & $43 \%$ \\
\hline Average Government Take (US \$/year) & $60,189,022$ & \\
\hline
\end{tabular}

The revenue split analysis suggest that the Operator revenue is estimated to be lower than Government revenue (figure 3). In average PT. PHE OSES take is projected at USD 56.414 million per year compared to USD 60.189 million of Government take.

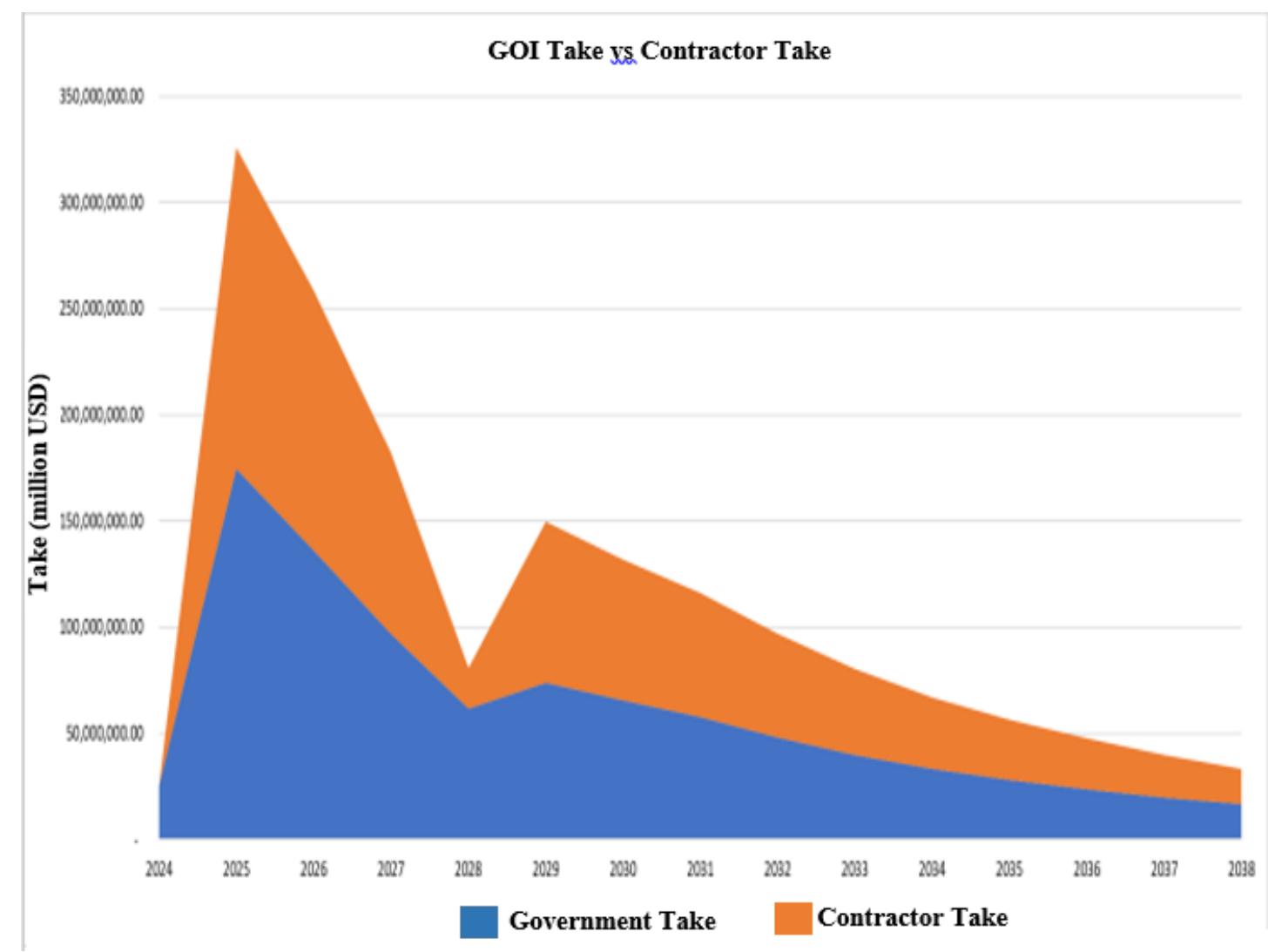

(Author Analysis, 2019)

Fig. 3. Split revenue forecast $2024-2038$.

The economic calculation shows (table 4) that under the Gross Split PSC, the investment is feasible as indicated by Contractor positive post-tax NPV of USD 110.55 million and
$26.06 \%$ IRR exceeds the discount rate. The Contractor's Net Cash Flow USD 391.63 million. 
TABLE IV. ECONOMic CALCUlation Result of Triple Has Prospect

\begin{tabular}{|l|l|l|l|}
\hline No & \multicolumn{1}{|c|}{ Parameters } & \multicolumn{1}{|c|}{ Units } & \multicolumn{1}{|c|}{ Result } \\
\hline 1 & Oil Production & MMBO & 26.66 \\
\hline 2 & Gas Production & BCF & 35.39 \\
\hline 3 & Gross Revenue & \$ Million & $2,090.80$ \\
\hline 4 & Total Capital Expenditures & \$ Million & 257.93 \\
\hline 5 & Total Operating Expenditures & \$ Million & 140.23 \\
\hline Contractor Take & \$ Million & 789.80 \\
\hline 6 & Total Contractor Take & $\%$ & $38 \%$ \\
\hline 7 & Total Contractor Take & \$ Million & 391.63 \\
\hline 8 & Cummulative Contractor Net Cash Flow & \$ Million & 110.55 \\
\hline 9 & NPV Contractor (Discount Rate 12.39\%) & \% & $26.06 \%$ \\
\hline 10 & IRR & \\
\hline Government Take & \$ Million & 902.84 \\
\hline 11 & Total Government Take & $\%$ & $43 \%$ \\
\hline 12 & Total Government Take & \\
\hline 13 & NPV Government (Discount Rate $\$$ Million & $\$ 498.04$ \\
\hline & $12.39 \%)$ & & \\
\hline
\end{tabular}

(Author Analysis, 2019)

Among these 6 factors, 2 of them are controllable by Contractor and create significant impact to the project economics: Oil production and Capital Expenditures. A 20\% change in Oil production will lead the Contractor's Net Cash Flow to change by $40.57 \%$ while the Contractor's Net Present Value is impacted by $80.94 \%$. While, a $20 \%$ change in Capital Expenditures will lead the Contractor's Net Cash Flow to change by $36.08 \%$ and the Contractor's Net Present Value is impacted by $90.94 \%$. The other contributing factors: Gas production, Gas price and Operational Expenditures are lesser contributing factors to Contractors NCF and NPV. Can be seen on figure 4 bellow.
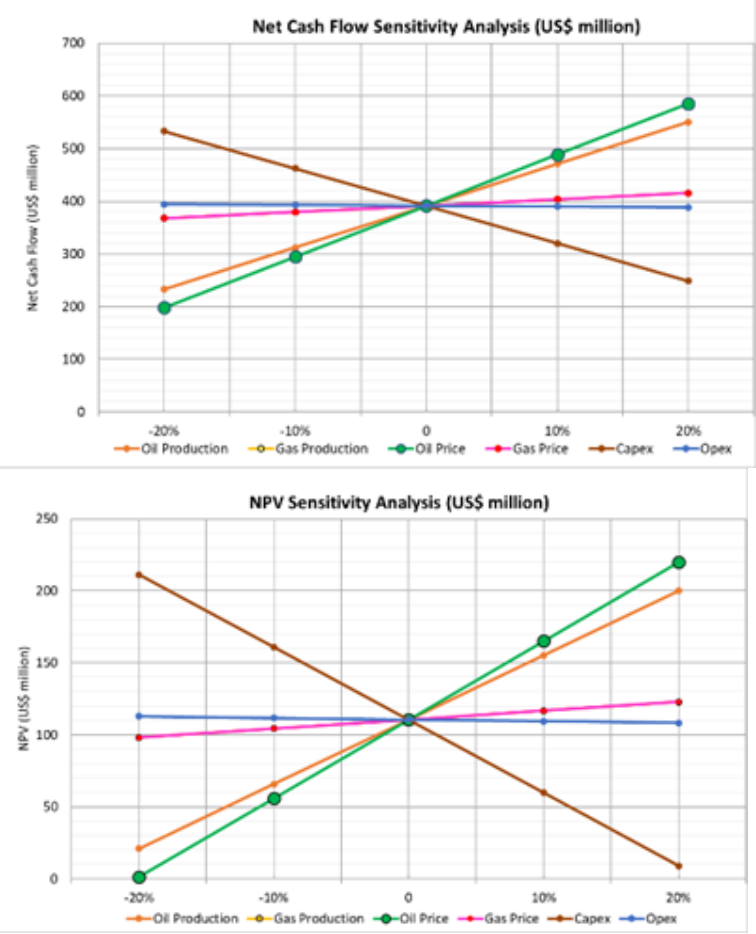

Fig. 4. Net cash flow \& net present value sensitivity analysis.

\section{CONCLUSION}

Porter's five Forces model external environmental analysis suggest that the Upstream of Oil and Gas business is still attractive for incumbent firms especially due to low threat of substitute and low threat of new entrants. However, it is not very attractive for new entrants mainly due to huge investment required to enter the business and the risk associated with the business. Moreover, the increasing demand to shift to renewable energy should be put into consideration in business decision making process.

From PESTEL perspective, Oil and gas demand primarily coming from emerging economies, which emphasize that the energy increase is corelate to population growth. The rate of growth in the demand for oil and gas will probably slowing down as the world switches towards gas and renewable sources of energy, but this change will take time, because existing infrastructure and capital investments have very long lives. Thus, the oil and gas industry will still play an important role in global economic growth, including Indonesia.

There are two factors that become obstacles for the oil and gas sector to grow, complex regulation (legal certainty) and bureaucracy. To stimulate oil and gas business, the regulation should be as simple as possible without jeopardizing the State interest. The Gross Split PSC that was introduced in 2017 was an example of the Government action to simplify the regulation in hope to stimulate the oil and gas business in Indonesia.

The economic simulation shows that using the Gross Split PSC, the investment is viable as indicated by positive Contractor after-tax NPV of USD 110.55 million and $26.06 \%$ IRR is more than the discount rate. The Contractor's Net Cash Flow USD 391.63 million.

Despite the profitability shown in the economic calculation, the NPV of Contractor (USD 110.55 million) is less compared to NPV of Government (USD 498.04 million). As also seen in the forecasted Contractor take (USD 789.80 million) compared to Government take (USD 902.84 million). With the risk of the explorations and productions activities borne by Contractor, it appears that offset of the economic parameters (NCF, NPV, Take) is not showing a dazzling result for Contractor perspective. Future discussion with the stakeholders in energy business might provide insights on stimulate the oil and gas business without jeopardizing the State interest.

Three variables that affecting significantly the NCF and NPV of Contractors in Triple-Has Prospect are: Oil price, Oil production and Capital Expenditures. A 20\% change in Oil Price will lead the Contractor's Net Cash Flow to increase or reduce by $49.44 \%$ while the Contractor's Net Present Value is impacted by $98.82 \%$. Gas production, Gas price and Operational Expenditures are lesser contributing factors to Contractors NCF and NPV. 


\section{REFERENCES}

[1] D. Johnston, International fiscal systems and production sharing contracts. Tulsa, OK: PennWell, 1994.

[2] S.A. Ross, R. Westerfield, and B.D. Jordan, Fundamentals of corporate finance. Tata McGraw-Hill Education, 2008

[3] H. Daniel, "Indonesian Milestone in Production-Sharing Contract in Perspective of Government Take, Contractor Take, Cost Recovery and
Production Target," In SPE/IATMI Asia Pacific Oil \& Gas Conference and Exhibition. Society of Petroleum Engineers, 2017.

[4] SKKMIGAS, Oil \& Gas Project Economic Calculation using Gross Split PSC Model. SKKMIGAS, 2019.

[5] L.J. Gitman, R. Juchau, and J. Flanagan, Principles of managerial finance. Pearson Higher Education AU, 2015.

[6] A. Damodaran, Applied corporate finance. John Wiley \& Sons, 2010. 